\title{
Utilization of the $\mathrm{Ni}_{0.1} \mathrm{Co}_{0.9} \mathrm{Fe}_{2} \mathrm{O}_{4}$ Nanocrystals for the Degradation of Crystal Violet
}

\author{
Amina I. Ghoneim ${ }^{1, *}$, Talaat M. Meaz ${ }^{1}$
}

${ }^{1}$ Physics Department, Faculty of Science, Tanta University, Tanta 31527,

Egypt

Corresponding Authors (*): mona_ghoneim@yahoo.com, amina.ali@science.tanta.edu.eg

Ultra-small $\mathrm{Ni}_{0.1} \mathrm{Co}_{0.9} \mathrm{Fe}_{2} \mathrm{O}_{4}$ nanocrystals were fabricated via the simple co-precipitation route, then annealed at $900 \mathrm{C} / 4 \mathrm{~h}$, and well-accurately scrutinized by X-ray diffracting strategy (XRD), FT-IR spectral plots, and high resolution transmitting electron microscopy (HRTEM) technique. $X R D$ scrutiny affirmed the emergence of the solitary-phase cubic spinel nanocrystals. The fine crystallite size $R$ average value was $36.265 \mathrm{~nm}$. FTIR absorption plots displayed the essential absorbing summits which were related to their essential sites and essential bonding types. All parameters were influenced by the subsistence of the $\mathrm{Ni2}+, \mathrm{Co} 2+$, and $\mathrm{Fe} 3+$ cations in these nanocrystals. HRTEM images showed accumulations for the nanoparticles, where the mean particle's size evaluation was $42.9 \mathrm{~nm}$ and was slightly bigger than the crystallite size R. Estimation of photocatalytic leverage for Ni0.1Co0.9Fe2O4 Nano-ferrites was obtained through the degradation of Crystal Violet $(\mathrm{CV})$ dye $(1 \times 10-5 \mathrm{M})$ in aqueous solution under visible light irradiation using 100 Watt Tungsten lamp fixed at $\sim 10$ $\mathrm{cm}$ distance. Consequently, usage of these ultrafine Ni0.1Co0.9Fe2O4 nanocrystals provides a new marvellous route for the motivation of costeffective technologies for quite good waste water recycling models, for 
raising water quality and for the advancement of fruitful efforts in improving treatment strategies.

Keywords: $\mathrm{Ni}_{0.1} \mathrm{Co}_{0.9} \mathrm{Fe}_{2} \mathrm{O}_{4}$ nanocrystals; $\mathrm{HTEM}$; Crystal Violet; Photodegradation; water treatment

\section{Introduction}

Photo-catalysts advancement for impure $\mathrm{H}_{2} \mathrm{O}$ remediation is a substantial aspect for environmentally ongoing inspection endeavours. Nano-spinels are softmagnetic semiconducting nanocrystals possessing supreme constancy, and visibly economical; thence these Nano-spinels are facilely fabricated and possess prevalent utilizations in miscellaneous prospects in electromagnets, NTC thermistors, electronical industries, magneto-caloric \& magnetic refrigeration, ferrofluids, satellite communications as well as theranostic applications of nanocrystals in medicine. Photo-catalytic effectiveness for dye decadence under visible light photons has exceedingly scrutinized within recent times. Organic dyes are vastly utilized in numerous industries manifesting carcinogenic impress in nature causing counteractive effectiveness on environmental sides. Subsequently, dissociation of such dyes is so essential, where dissociation by photo-catalysis is one of the most effective routes for $\mathrm{H}_{2} \mathrm{O}$ up-cleaning [1]. Semiconducting photocatalytic strategy asserted an auspicious methodology for environmentally polluted handling imputing to their entire dissociations from organic contaminations into $\mathrm{CO}_{2}$ and $\mathrm{H}_{2} \mathrm{O}$ at ambient status [2]. Iron oxides and Nano-spinels are utilized as one of expectant and elegant semiconducting nanocrystals; thence they have invigorated splendid inspection vistas assigning to their distinguished merits. Continual attempts have widened to motivate photocatalytic implementation of Iron oxides and Nano-spinels [3]. Inspection attempts in nanoscience have utility towards numerous prospects such as: fabrication, scrutiny of new nanostructures. Vigour of Nanocrystals in fields like telecommunication technology and photo-catalysis is increasing due to the elicited marvellous merits of such nanocrystals [4,5]. 
Obviously, utilization of Nano-spinel is so efficient in dismantling of organic dyes, where these nanocrystals raise the efficiency of this procedure. This aspect has been early emphasized by [5], utilizing $\mathrm{ZnFe}_{2} \mathrm{O}_{4}$ in this aspect confirming their impress in dye degradation. Thus, current inspection focuses on fabricating new nanocrystals $\left(\mathbf{N i}_{\mathbf{0}_{0.1}} \mathbf{C o}_{0.9} \mathbf{F e}_{2} \mathbf{O}_{4}\right.$ Nano-spinels) and distinguishing their merits. As well as examining their capability in Crystal Violet dissociation. Evaluation of photocatalytic effectiveness for $\mathbf{N i}_{\mathbf{0}_{\text {.1 }}} \mathbf{C o}_{\mathbf{0} .9} \mathbf{F e}_{2} \mathbf{O}_{\mathbf{4}}$ Nano-ferrites was obtained through the dissociation of Crystal Violet $(\mathbf{C V})$ in aqueous solution under visible light (VL) irradiation using 100 Watt Tungsten lamp fixed at $~ 10$ cm distance.

\section{Experimental Techniques}

\subsection{Preparation of $\mathrm{Ni}_{0.1} \mathrm{Co}_{0.9} \mathrm{Fe}_{2} \mathrm{O}_{4}$ nanoparticles}

As-fabricated $\mathbf{N i}_{0.1} \mathbf{C o}_{0.9} \mathbf{F e}_{2} \mathbf{O}_{4}$ Nano-spinels have been fabricated using coprecipitation route according to the formula [6]:

\section{$0.1 \mathrm{NiCl}_{2} .6 \mathrm{H}_{2} \mathrm{O}+0.9 \mathrm{CoCl}_{2}+2 \mathrm{FeCl}_{3}+8 \mathrm{NaOH} \rightarrow \mathrm{Ni}_{0.1} \mathrm{Co}_{0.9} \mathrm{Fe}_{2} \mathrm{O}_{4}+8 \mathrm{NaCl}$ $+4.6 \mathrm{H}_{2} \mathrm{O}$}

Detailed Procedure of Co-precipitation have already been reported by Amer, et al 2014 [6]. Then, heated up to $900{ }^{\circ} \mathrm{C} / 4 \mathrm{~h}$, then cooled to ambient temperature, thereafter the ultrafine dried precipitates were finely ground in a sterilized agate mortar to obtain the Nano-powder [6].

\subsection{Characterizations:}

Nano-ferrites were scrutinized via GNR APD 2000 Pro X-ray diffractometer step scan type and $\mathrm{CuK} \alpha_{1}$ radiation at wavelength $\lambda=1.540598 \AA$. Lattice cons a for $\mathbf{N i}_{0.1} \mathrm{Co}_{0.9} \mathrm{Fe}_{2} \mathrm{O}_{4}$ Nano-spinels was contrived exploiting the expression; $\mathrm{a}=\mathrm{d}\left(\mathrm{h}^{2}+\right.$ $\left.\mathrm{k}^{2}+\mathrm{l}^{2}\right)^{1 / 2}$, whilst $\mathrm{d}$ is the inter-planar widening elicited by exploiting Bragg's expression; $2 \mathrm{~d} \sin \theta=\mathrm{n} \lambda$, and $\theta$ is Bragg's angular position [7]. FT-IR spectra for all nano-samples were explored by using Bruker-Tensor-27-FT-IR - type Spectrometer in the range 200 to $2000 \mathrm{~cm}^{-1}$, at room temperature. Force cons $\mathrm{F}_{1}$ and $F_{2}$ for $A$ - and $B$-sites was determined using the equation; $F_{c}=4 \pi^{2} C^{2} v^{2} \mu$, 
where $\mathrm{C}$ is light rapidity, $\nu$ is the vibrational frequency and $\mu$ is the reduced mass of ions, $\mu$ equals about $2.061 \times 10^{-23}$ gm [8,9]. Moreover, the average nanoparticle size and morphology have been determined by the high resolution transmitting electron microscope of the kind JEOL JEM - 2100 Electron Microscope. UV-vis spectra were registered using SPECTRO UV-VIS DUAL BEAM 8 AUTO CELL UVS-2700 scan-type spectrophotometer in the wavelengths 190-1200 nm at ambient temperature.

\subsection{Photocatalytic activity of $\mathrm{Ni}_{0.1} \mathrm{Co}_{0.9} \mathrm{Fe}_{2} \mathrm{O}_{4}$ nanocrystals:}

Photocatalytic features of $\mathrm{Ni}_{0.1} \mathrm{Co}_{0.9} \mathrm{Fe}_{2} \mathrm{O}_{4}$ nanocrystals were scrutinized by photo-degradation of the simulation of dye waste-water of the crystal violet (CV) soln under VL utilizing 100 Watt Tungsten lamp fixed at $\sim 10 \mathrm{~cm}$ distance, as illuminated in Fig. 1. Aqueous suspension of $\mathbf{C V}$-dye $\left(\mathbf{1} \times \mathbf{1 0}^{-\mathbf{5}} \mathbf{M}\right)$ and $\mathbf{N i}_{0.1} \mathbf{C o}_{0.9} \mathbf{F e}_{2} \mathbf{O}_{4}$ nanocrystals as photo-catalysts $(0.1 \mathrm{~g})$ was placed in a glass beaker. Before irradiation, each suspension was stirred in dark for $2 \mathrm{~h}$ to establish adsorption-desorption equilibrium (between photo-catalyst and dye), followed by VL irradiation utilizing 100 Watt Tungsten lamp fixed at $\sim 10 \mathrm{~cm}$ distance. At time spans $(1 \mathrm{~h}), 3 \mathrm{~mL}$ of suspension was continuously isolated from the beaker, and then filtered to remove the solid powders. Later, the solutions were analysed by the SPECTRO UV-VIS DUAL BEAM 8 AUTO CELL UVS-2700 scan-type spectrophotometer in the wavelengths $190-1200 \mathrm{~nm}$ at ambient temperature to obtain the relative concentration variations of the solution. The curve about the concentration variations $\left(\mathbf{C} / \mathbf{C}_{\mathbf{0}}\right)$ as a function of time was plotted, where $\mathbf{C}$ presented $\mathbf{C V}$ concentration at each time span and $\mathbf{C}_{\mathbf{0}}$ was $\mathbf{C V}$ initial concentration after reaching adsorption-desorption equilibria [10]. 


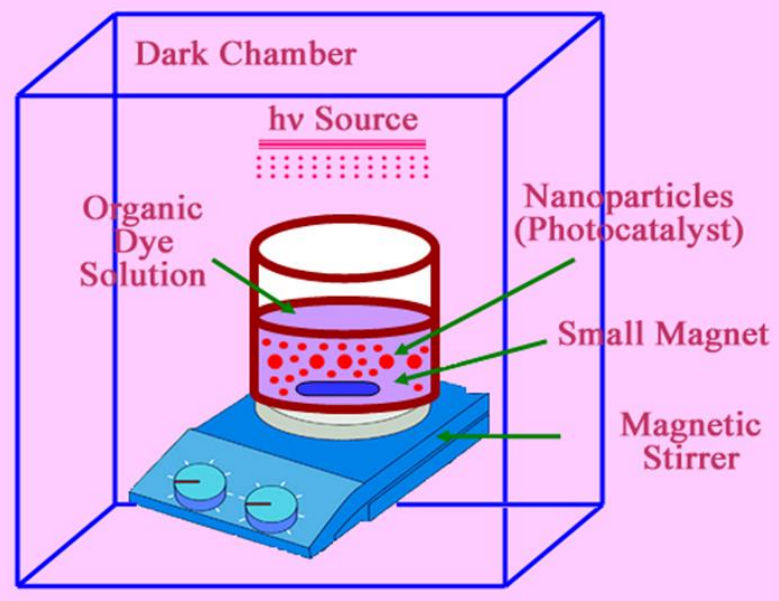

Fig. 1 Schematic illustration of the experimental apparatus setup used for PhotoDegradation mechanism of Crystal Violet (CV) over surface of ultrafine $\mathrm{Ni}_{0.1} \mathrm{Co}_{0.9} \mathrm{Fe}_{2} \mathrm{O}_{4}$ Nanocrystals.

\section{Results and discussion}

\subsection{X-ray diffracting plots (XRD)}

$\mathbf{N i}_{0.1} \mathbf{C o}_{0.9} \mathbf{F e}_{2} \mathbf{O}_{4}$ nanocrystals annealed at $900 \mathrm{C} / 4 \mathrm{~h}$ affirmed the complete egress of Nano-spinels monocular-phase which was exquisitely explored by XRD diagrams in Fig. 2. Protruded peaks in XRD diagrams affirm the one-phase Nanospinel after analogy with JCPDS cards no. 00-001-1121. Plainly, for the ultrasmall nano-regime merit of these Nanocrystals thus emerges relatively broader XRD summits in Fig. 2, as further emphasized regarding their fine crystallite sizes for all nanoparticles as indicated in Table 1. Lattice constant a is ranging $\approx$ $8.479 \AA$ Agreeing with early scrutinized work [11]. Elucidated crystallite size R ranges $\approx 36.265 \mathrm{~nm}$, which lies in the Nano-scale ambit.

Obviously, S discloses reliance on both the delicate crystallite size R and X-ray density $\mathrm{D}_{x}$, and $\varepsilon$ relies on R. Since, Nano-spinels have teeny crystallite sizes, so that, they possess large specified surface areas [12]. $\mathrm{S}$ and $\varepsilon$ estimations are 
illuminated in Table 1, which matches well with the posteriorly done appreciations [13]. Unit cell volume $\mathrm{V}$ and $\mathrm{X}$-ray densitiy $\mathrm{D}_{x}$ are presented in Table 1.

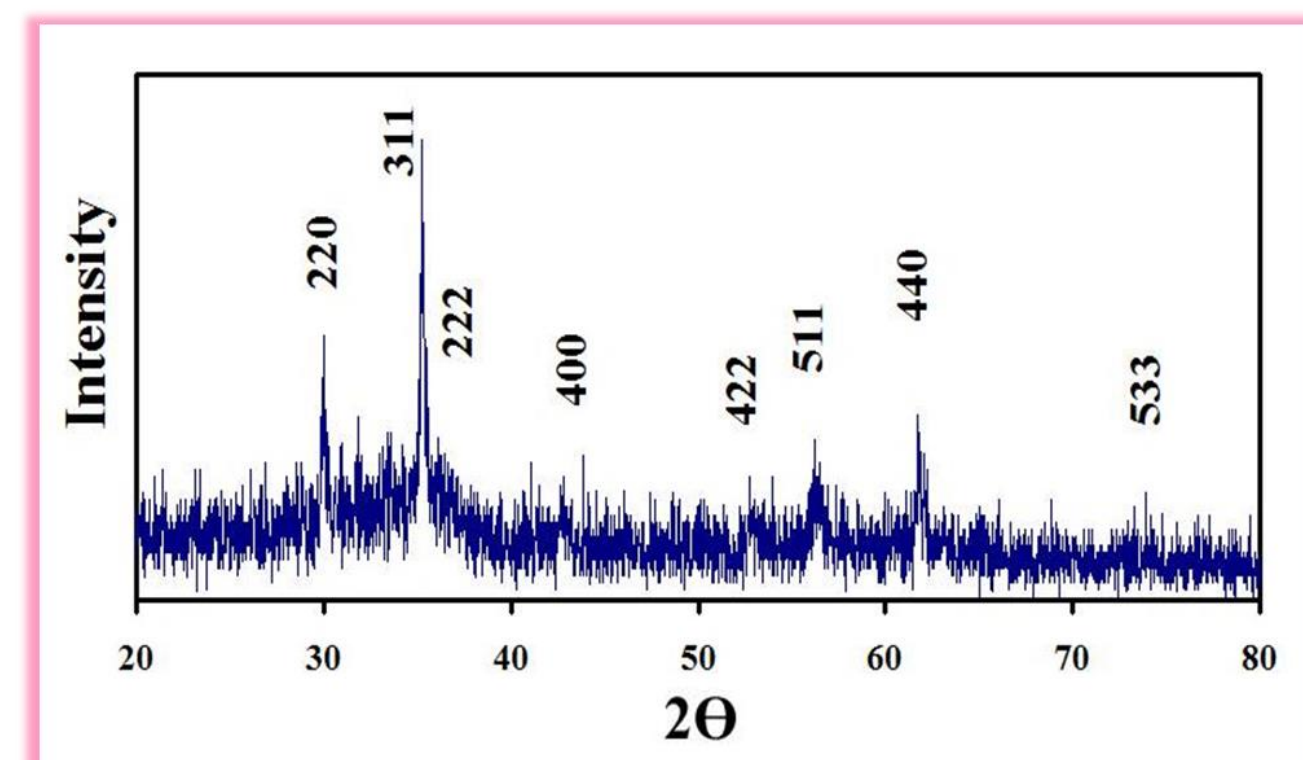

Fig. 2 XRD plots of Nano-spinel $\mathbf{N i}_{0.1} \mathbf{C o}_{0.9} \mathbf{F e}_{2} \mathbf{O}_{4}$, heated at $900{ }^{\circ} \mathrm{C}$.

Table 1 Lattice parameter a, crystallite size R, strain $\varepsilon$, unit cell volume V, X-ray density $\mathrm{D}_{x}$, specified surface area $\mathrm{S}$, distortion parameter $\mathrm{g}$ and dislocation density $\delta$, error $= \pm 0.02$.

\begin{tabular}{|c|c|c|c|c|c|c|c|c|}
\hline Nano-spinel & (̊) & $\begin{array}{c}\mathbf{R} \\
(\mathbf{n m})\end{array}$ & $\boldsymbol{\varepsilon}$ & $\begin{array}{c}\mathbf{V} \\
(\AA)^{3}\end{array}$ & $\begin{array}{c}\mathbf{D}_{x} \\
(\mathrm{gm} . \mathrm{cm} \\
-3 \text { ) }\end{array}$ & $\begin{array}{c}\mathrm{S} \\
\left(\mathrm{m}^{2} / \mathrm{g}\right)\end{array}$ & $\mathbf{g}$ & $\begin{array}{c}\delta \\
\left(\mathrm{nm}^{-2}\right) \times \\
10^{-2}\end{array}$ \\
\hline $\begin{array}{c}\mathrm{Ni}_{0.1} \mathrm{Co}_{0.9} \mathrm{Fe}_{2} \mathrm{O} \\
4\end{array}$ & $\begin{array}{c}8.47 \\
9\end{array}$ & $\begin{array}{c}36.26 \\
5\end{array}$ & $\begin{array}{c}- \\
0.0283\end{array}$ & $\begin{array}{c}609.4 \\
5\end{array}$ & 5.114 & $\begin{array}{c}32.36 \\
1\end{array}$ & $\begin{array}{c}0.012 \\
6\end{array}$ & 0.076 \\
\hline
\end{tabular}




\subsection{Structural Phase Analysis}

Dimensional cell volume's for these Spinels was contrived utilizing the formulation [14]; $V_{\text {cell }}=a^{3}$. Dimensional cell volume $\mathrm{V}$ disclosed a precise value reaching $\approx 609.45(\AA)^{3}$, (Table 1).

X-ray density was well contrived utilizing the formula [15]:

$$
D_{X}=\frac{Z M}{N_{A} V}
$$

, $\mathrm{Z}$ is molecules no. per unit cell $(Z=8) ; M$ is molecular weight and $N A$ is Avogadro's no.

Dislocation density $\delta$ was contrived utilizing the expression [16]:

$$
\delta=\frac{1}{R^{2}}
$$

; $\mathrm{R}$ is crystallites sizes.

Distortion parameter $\mathrm{g}$ was contrived utilizing the formula [16]:

$$
\mathrm{g}=\frac{\beta_{1 / 2}}{\tan \theta}
$$

Table 1 discloses dependence of $\mathrm{g}$ and $\delta$ on $\mathrm{R}$ and $\theta$, whilst $\mathrm{g}$ and $\delta$ rely on interior amendments in Nanocrystal's lattice spacing and oxygen ion concentration [16].

Specified surface area $\mathrm{S}$ of Nano-spinels was contrived utilizing [12];

$$
S=\frac{6000}{R_{X R D} D_{x}}
$$

Strain $\varepsilon$ of Nano-spinels was contrived utilizing the formula [12];

$$
\beta_{1 / 2} \cos \theta=\frac{0.94 \lambda}{R_{X R D}}+4 \varepsilon \sin \theta
$$


Strain $\varepsilon$ interior these Nano-spinels relies on cations type and their crystallographic configuration, (Table 1), as well as the protruded crystalline anisotropy [17]. Whilst, specified surface area $S$ revealed a high estimation reaching $\approx 32.361 \mathrm{~m}^{2} / \mathrm{g}$, imputing to the teeny crystallite size $\mathrm{R}$, (Table $\mathbf{1}$ ).

By plotting the relation between $\beta_{\frac{1}{2}} \cos \theta$ and $4 \sin \theta$ for each sample as traight line is obtained its slope gives the strain value. It is seen that $\varepsilon$ values are negative, which reveals compressive strain.

\subsection{FT-IR Spectral plots}

FT-IR spectral plots for $\mathbf{N i}_{0.1} \mathbf{C o}_{0.9} \mathbf{F e}_{2} \mathbf{O}_{4}$ nanocrystals annealed at $900 \mathrm{C} / 4 \mathrm{~h}$ registered from 200 to $2000 \mathrm{~cm}^{-1}$ in Fig. 3. Protruded vibrational summits of IR are illuminated in Table 2. Six oscillation summits of $v_{1}, v_{2}, v_{4}, v_{\mathrm{A}}, v_{\mathrm{B}}$ and $v_{\mathrm{T}}$ emerged in FT-IR spectral plots. $v_{1}$ at $605.631 \mathrm{~cm}^{-1}$ and $v_{2}$ at $420.471 \mathrm{~cm}^{-1}$, (Table 2), referred to substantial sprawl oscillations of A-occupational allocations ligations; whereas enormous recapture strengths for bond-bending oscillations subsist on B-occupational allocations [18]. Predominately, affirmation of the emersion of Nano-spinel configuration is affirmed by the entity of $v_{1}$ and $v_{2}$. Likewise, it was monitored that vibrational summit at $231.452 \mathrm{~cm}^{-1}$ for $v_{4}$ referring to lattice oscillations of Nano-Spinel configuration and it relies on lumps of entirety of A-occupational allocations divalent cations and their ligaments, $\mathrm{Fe}^{2+}-\mathrm{O}^{2-}, \mathrm{Co}^{2+}-\mathrm{O}^{2-}$ and/or $\mathrm{Ni}^{2+}-\mathrm{O}^{2-} \quad[6,19]$. Ternary vibrational summit $v_{\mathrm{T}}$ was unfolded around $\sim 1629.809 \mathrm{~cm}^{-1}$ and was assigned to the retained $\mathrm{H}_{2} \mathrm{O}$ in Nano-Crystals [20]. Nonlinear $\mathrm{H}_{2} \mathrm{O}$ molecule has 3- substantial oscillational status: symmetric, asymmetric stretching and scissoring oscillation status [20]. Vibrational summits around 898.805 and $1060.82 \mathrm{~cm}^{-1}$, orderly are referring to the vibrational summits $v_{\mathrm{A}}$ and $v_{\mathrm{B}}$. Vibrational summit $v_{\mathrm{A}}$ refer to coexistence of $\mathrm{Fe}^{2+}, \mathrm{Co}^{2+}$ amongst the A- sites. Vibrational summit $v_{\mathrm{B}}$ refer to coexistence of $\mathrm{Fe}^{4+}-\mathrm{O}^{2-}$ and $\mathrm{Ni}^{2+}-\mathrm{O}^{2-}$ cations. The protrude of $\mathrm{Fe}^{4+}$ cations impute to electronical jumping in-between $\mathrm{Fe}^{3+}$ and $\mathrm{Co}^{2+}$ cations [6]. 


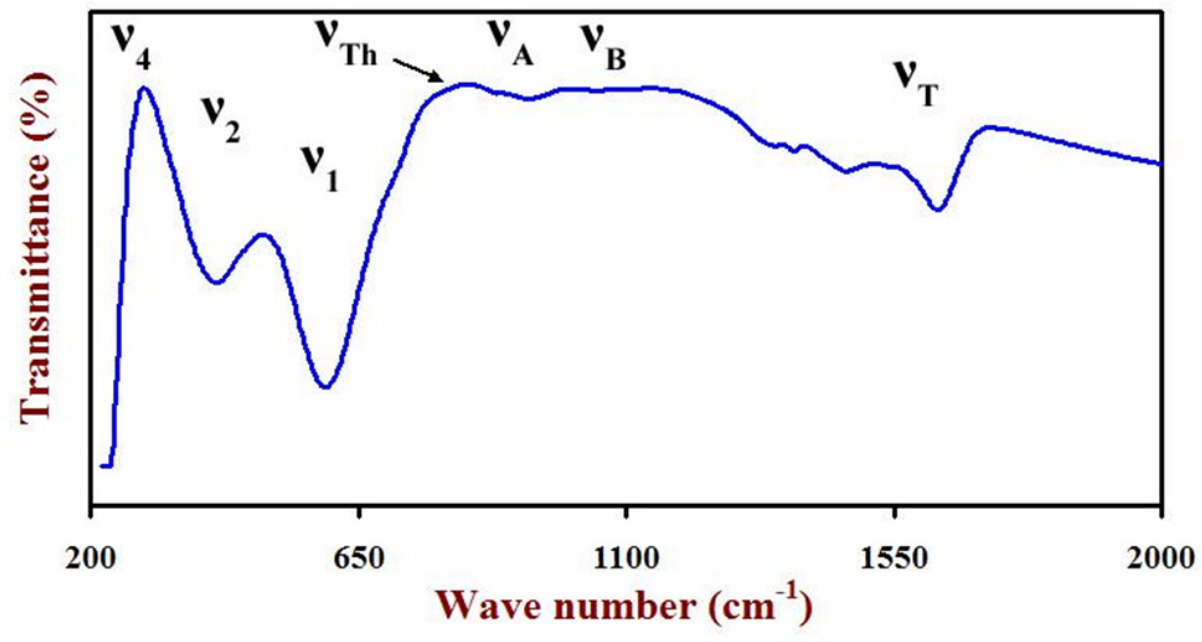

Fig. 3 FT-IR spectral plots of Nano-spinel $\mathbf{N i}_{\mathbf{0}_{1.1}} \mathbf{C o}_{0.9} \mathbf{F e}_{2} \mathbf{O}_{4}$, heated at $900{ }^{\circ} \mathrm{C}$.

Table 2 FT-IR vibrational summits positions $v_{n} ; n=1,2, \ldots$ and $B$, Threshold frequency $v_{T h}$, Threshold energy $E_{T h}(\mathrm{eV})$, Debye temperature $\Theta_{\mathrm{D}}$, Force con $F_{1}$ and $F_{2}$, error $= \pm 0.02$.

\begin{tabular}{|c|c|c|c|c|c|c|c|c|c|c|c|}
\hline Nano-spinel & $\begin{array}{c}\mathbf{v}_{\mathbf{1}} \\
\left(\mathbf{c m}^{-1}\right)\end{array}$ & $\begin{array}{c}\mathbf{v}_{\mathbf{2}} \\
\left(\mathbf{c m}^{-1}\right)\end{array}$ & $\begin{array}{c}\mathbf{v}_{\mathbf{4}} \\
\left(\mathbf{c m}^{-1}\right)\end{array}$ & $\begin{array}{c}\mathbf{v}_{\mathbf{A}} \\
\left(\mathbf{c m}^{-1}\right)\end{array}$ & $\begin{array}{c}\mathbf{v}_{\mathbf{B}} \\
\left(\mathbf{c m}^{-1}\right)\end{array}$ & $\begin{array}{c}\mathbf{v}_{\mathbf{T}} \\
\left(\mathbf{c m}^{-1}\right)\end{array}$ & $\begin{array}{c}v_{T h} \\
\left(\mathbf{c m}^{-1}\right)\end{array}$ & $\begin{array}{c}E_{T h} \\
(\mathbf{e V})\end{array}$ & $\begin{array}{c}\Theta_{\mathbf{D}} \\
(\mathbf{K})\end{array}$ & $\begin{array}{c}\mathbf{F}_{1} * \mathbf{1 0}^{\mathbf{5}} \\
(\mathbf{d y n e} / \mathbf{c m})\end{array}$ & $\begin{array}{c}\mathbf{F}_{2} * \mathbf{1 0}^{\mathbf{5}} \\
(\mathbf{d y n e} / \mathbf{c m})\end{array}$ \\
\hline $\mathbf{N i}_{\mathbf{0} . \mathbf{1}} \mathbf{C o}_{\mathbf{0} .9} \mathbf{F e}_{\mathbf{2}} \mathbf{O}_{\mathbf{4}}$ & 605.631 & 420.471 & 231.452 & 898.805 & 1060.82 & 1629.81 & 821.61 & 0.102 & 737.767 & 2.686 & 1.295 \\
\hline
\end{tabular}

Debye temperature was contrived via [21]:

$$
\theta_{D}=\frac{\hbar C v_{a v}}{k}=1.438 v_{a v} \quad \text { and } \quad v_{A V}=\frac{v_{1}+v_{2}}{2}
$$

, $v_{a v}$ is mean value of wave no's of vibrational summits, $\hbar=\mathrm{h} / 2 \pi, \mathrm{h}$ is the Plank's cons, $\mathrm{k}$ is Boltzmann's cons, $\mathrm{C}=3 \times 10^{10} \mathrm{~cm} / \mathrm{s} ; \mathrm{C}$ is light rapidity and $\hbar C / k=$ 1.438 for Nano-spinels [21]: $\theta_{D}$ nearly $\approx 737.767 \mathrm{~K}$ and impressed by wave no. of IR vibrational summits [21]. 
Concerning specified thermic theorem; the egress of conduction electrons portion (n-type transporters) that fundamentally procure somewhat of thermic potency declining its saucepan, and this bolsters the connotation that conduction impute to electrons, and vice versa. Sill threshold frequency $v_{T h}$ is subsisting at $821.61 \mathrm{~cm}^{-1}$ owing to the transition electrons, while $v_{T h}$ can be egressed from supreme spot of FT-IR spectral plots [22]; thence, conduction electron no's possess leverage on $v_{T h}$ and $\theta_{\mathrm{D}}$. Evolved estimation of force cons $\mathrm{F}_{1}$ and $\mathrm{F}_{2}$ for $\mathrm{A}-$ and $\mathrm{B}-$ occupational allocations orderly equals $2.686 \times 10^{5}$ and $1.295 \times 10^{5} \mathrm{dyne} / \mathrm{cm}$, asserting reliance of $F_{1}$ and $F_{2}$ on oscillational frequencies at these allocations, (Table 2).

Substantially, Threshold energy was contrived utilizing the expression [9]:

$$
E_{T h}=h C v_{T h}
$$

, where $\mathrm{h}$ is Plank's cons, $\mathrm{C}=3 \times 10^{10} \mathrm{~cm} / \mathrm{s}$; $\mathrm{C}$ is light rapidity, $v_{T h}$ is the threshold frequency. Contrived evaluation of $v_{T h}$ and $E_{T h}$ are presented in Table 2.

Threshold vibrational summit $v_{T h}$ emerged around $821.61 \mathrm{~cm}^{-1}$ shifting towards higher frequencies imputing to the high concentration of $\mathrm{Fe}^{2+}$ and $\mathrm{Fe}^{3+}$ and as well imputing to the increased hopping status between $\mathrm{Fe}^{2+}, \mathrm{Fe}^{3+}$ and $\mathrm{Fe}^{4+}$ cations as disclosed in the following expression: $\quad \mathrm{Fe}^{2+}+\mathrm{Fe}^{4+} \leftrightarrow$ $\mathrm{Fe}^{3+}$

Thence, the threshold energy $E_{T h}$ possesses high evaluation going directly on the same demeanour as that of $v_{T h}$ directly depending on the early estimation of $v_{T h}$, (Table 2).

\subsection{HRTEM images}

HRTEM pics of $\mathbf{N i}_{\mathbf{0 . 1}} \mathbf{C o}_{0.9} \mathbf{F e}_{2} \mathbf{O}_{4}$ Nano-spinels are affirmed in Fig. 4. The pics explore that nanoparticles are accumulated imputing to their magnetic moments. The mean nanoparticle size $\mathrm{Z}$ reaches $\approx 42.9 \mathrm{~nm}$. It is obvious that, $\mathrm{Z}$ evaluation is closer to that of $\mathrm{R}$, where $\mathrm{Z}$ is lightly enormous which refer to the 
thinning amorphous layer on the nanoparticle's superficies. That is owing to XRD picks only the well-crystalline section interior nanoparticles, whilst HRTEM pics provide complete pics of nanoparticles [11,23].

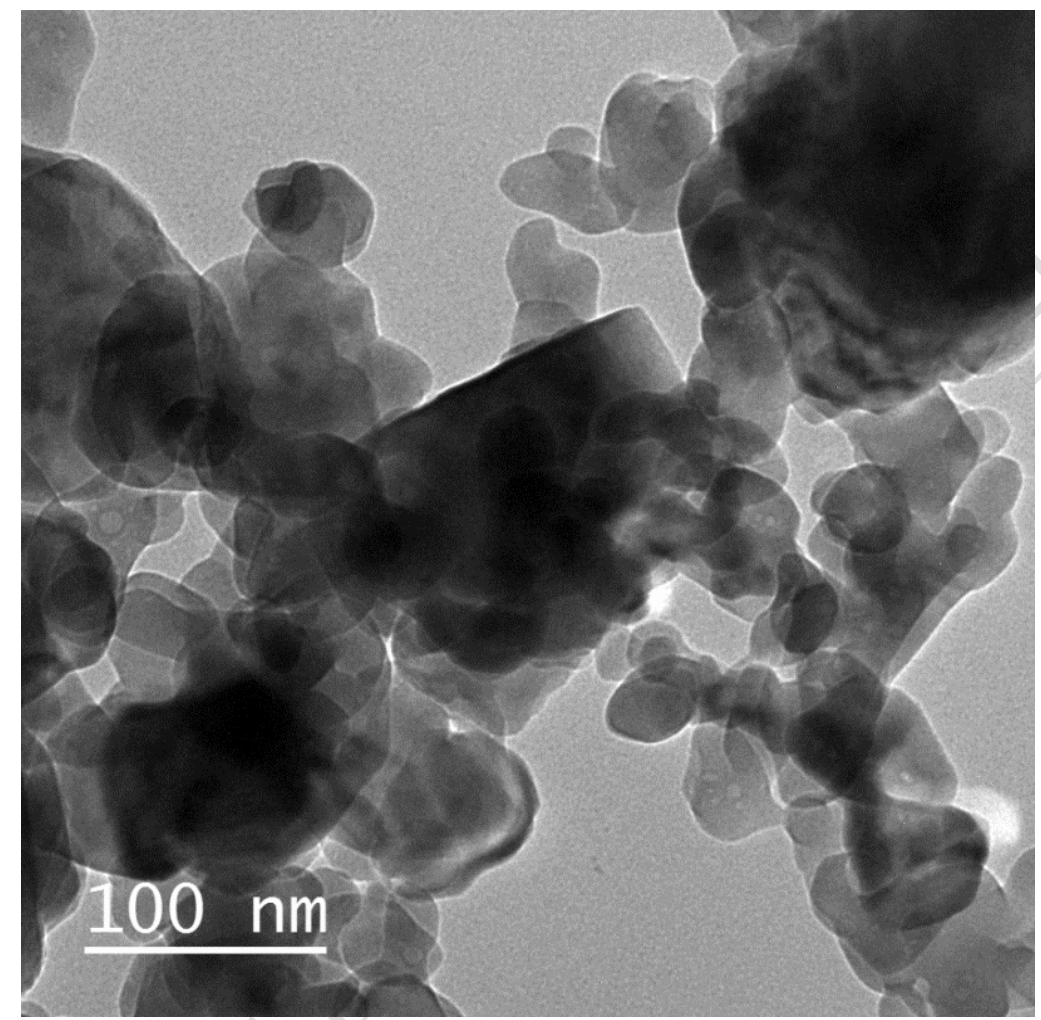

Fig. 4 HTEM pics of Nano-spinel $\mathbf{N i}_{0.1} \mathbf{C o}_{0.9} \mathbf{F e}_{2} \mathbf{O}_{4}$, heated at $900{ }^{\circ} \mathrm{C}$.

\subsection{Photocatalytic features:}

Photo-catalytic performance of $\mathbf{N i}_{0.1} \mathbf{C o}_{0.9} \mathbf{F e}_{2} \mathbf{O}_{4}$ Nano-spinels annealed at $900 \mathrm{C}$ 14h for the sequent decolourization of Crystal Violet $(\mathbf{C V})$ dye $\left(\mathbf{1} \times \mathbf{1 0}^{-5} \mathbf{M}\right)$ in aqueous soln under VL irradiation using 100 Watt Tungsten lamp fixed at $\sim 10$ $\mathrm{cm}$ distance, examined under surging of sequent spans of time up to 9 hours, (time duration is 1 hour) were affirmed in Fig. 5. All catalytic degradation reactions followed pseudo-first-ordering kinetics, affirmed by plots of $(\mathbf{C} / \mathbf{C o})$ versus time (h), as well as the plots of $\mathbf{l n}(\mathbf{C} / \mathbf{C o})$ versus reaction time (h), (Fig. 5). It is explicit that, $\mathbf{C V}$ concentrations continuously decline with surge of stirring 
time emphasizing the photocatalytic activity of these Nano-spinels [24]. Degradation Efficiency was elicited via [25]:

$$
\text { Degradation }- \text { Efficiency }=\left(1-\frac{C}{C_{o}}\right) \times 100
$$

Photo-catalytic efficiency of $\mathbf{N i}_{0.1} \mathbf{C o}_{0.9} \mathrm{Fe}_{2} \mathbf{O}_{4}$ Nano-spinels for $\mathbf{C V}$ degradation was explicitly explored on Fig. 6, proofing surging of their capability and activity in photo-degradation of $\mathbf{C V}$, and referring to how high quality will be the treated $\mathrm{H}_{2} \mathrm{O}$ by this procedure.
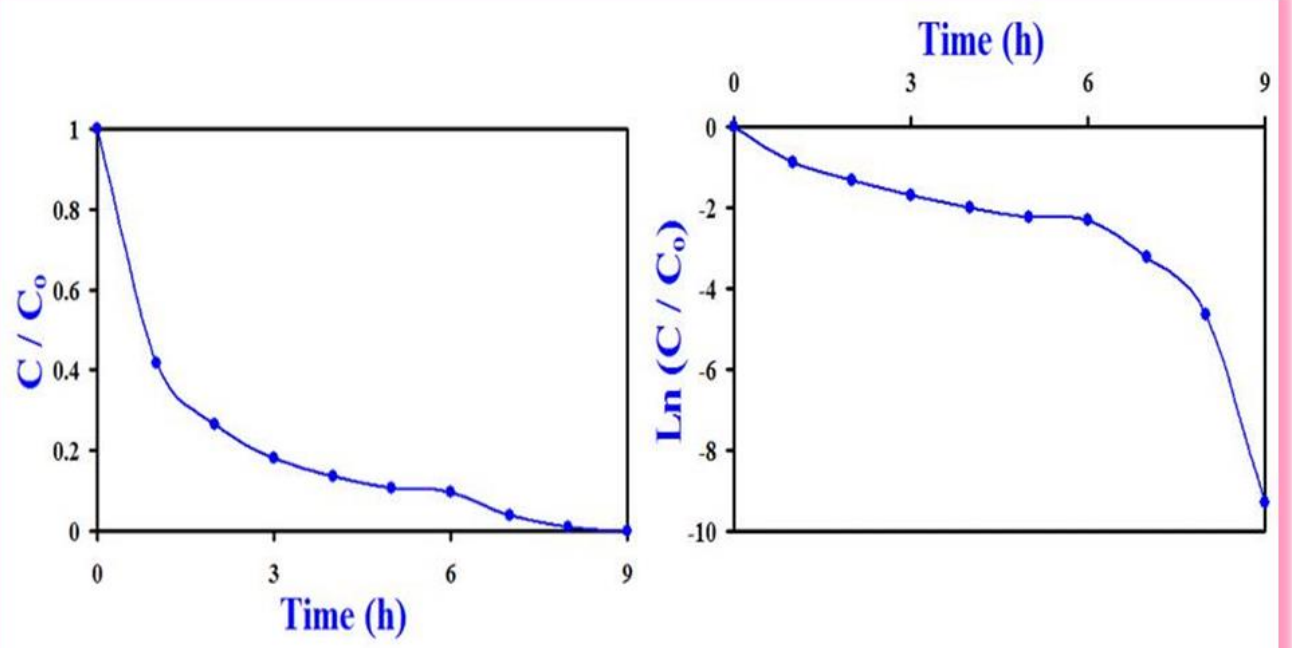

Fig. 5 Photo-Degradation of $\mathrm{CV}\left(\mathbf{1} \times \mathbf{1 0} \mathbf{0}^{-5} \mathrm{M}\right)$ utilizing $\mathrm{Ni}_{0.1} \mathrm{Co}_{0.9} \mathrm{Fe}_{2} \mathrm{O}_{4}$ Nanospinels as photo-catalysts, with time duration 1 hour. 


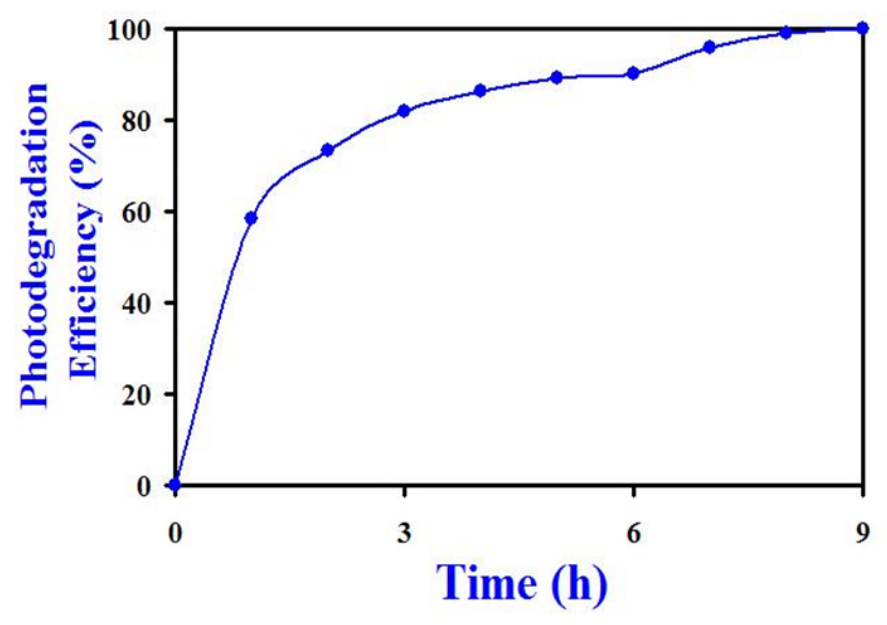

Fig. 6 Photo-catalytic efficiency of $\mathrm{Ni}_{0.1} \mathrm{Co}_{0.9} \mathrm{Fe}_{2} \mathrm{O}_{4}$ Nano-spinels for $\mathrm{CV}\left(1 \times \mathbf{1 0}^{-}\right.$ ${ }^{5}$ M) degradation, with time duration 1 hour.

Manifestly, precise utilization of the extremely ultrafine $\mathrm{Ni}_{0.1} \mathbf{C o}_{0.9} \mathrm{Fe}_{2} \mathrm{O}_{4}$ nanocrystals protrude a new exquisite route for the promotion of echo-friendly technologies for quite delicate waste water reclaiming archetypes, for surging $\mathrm{H}_{2} \mathrm{O}$ quality and for the furtherance of effectual exertions in ameliorating treatment mechanisms.

Fig. 7 illuminates the gradual photo-degradation as well as the sequent decolourization of Crystal Violet $(\mathbf{C V})$ dye $\left(\mathbf{1} \times \mathbf{1 0}^{-5} \mathbf{M}\right)$ in aqueous soln under VL irradiation using 100 Watt Tungsten lamp fixed at $\sim 10 \mathrm{~cm}$ distance, examined under surging of sequent spans of time up to 9 hours, (time duration is 1 hour), utilizing $\mathbf{N i}_{0.1} \mathbf{C o}_{0.9} \mathbf{F e}_{2} \mathbf{O}_{4}$ Nano-spinel as photo-catalyst. 
Photo-Degradation of Crystal Violet

$$
\text { (CV) }\left(1 \times 0^{-5} \mathrm{M}\right)
$$

with time duration ( 1 hour ).

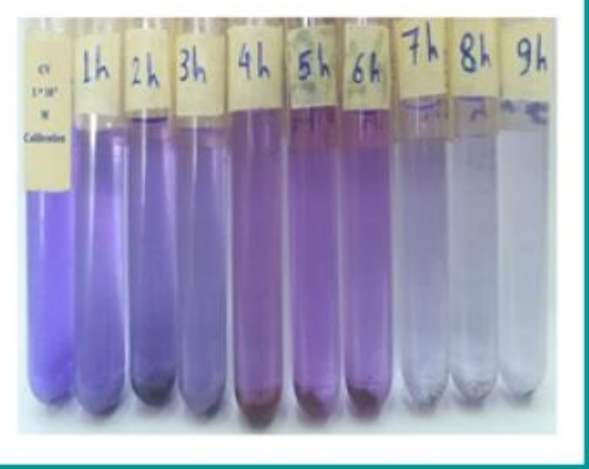

Fig. 7 Gradual photo-degradation and decolourization of Crystal Violet (CV) dye $\left(\mathbf{1} \times \mathbf{1 0}^{-5} \mathrm{M}\right)$ with time duration 1 hour utilizing $\mathbf{N i}_{\mathbf{0 . 1}} \mathbf{C o}_{0.9} \mathbf{F e}_{2} \mathbf{O}_{4}$ Nano-spinel as photo-catalyst.

Fig. 8 sheds light on the sequent photocatalytic degradation mechanism of Crystal Violet $(\mathbf{C V})$ dye $\left(\mathbf{1} \times \mathbf{1 0}^{-5} \mathbf{M}\right)$ in aqueous soln under VL irradiation using 100 Watt Tungsten lamp fixed at $\sim 10 \mathrm{~cm}$ distance, inspected under surging of sequent spans of time up to 9 hours, (time duration is 1 hour), utilizing $\mathrm{Ni}_{0.1} \mathrm{Co}_{0.9} \mathrm{Fe}_{2} \mathrm{O}_{4}$ Nano-spinel that acts as photo-catalyst.

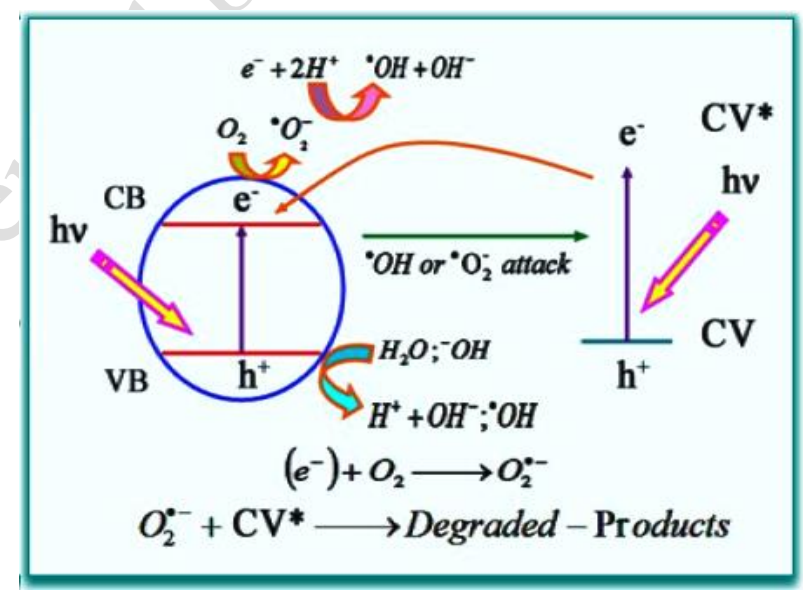

Fig. 8 The sequent photocatalytic degradation mechanism of Crystal Violet (CV) dye $\left(\mathbf{1} \times \mathbf{1 0}^{-5} \mathbf{M}\right)$, utilizing $\mathbf{N i}_{0.1} \mathbf{C o}_{0.9} \mathbf{F e}_{2} \mathbf{O}_{4}$ Nano-spinel as photo-catalyst, under visible light irradiation, with time duration 1 hour. 


\section{Conclusion}

Ultra-small $\mathrm{Ni}_{0.1} \mathrm{Co}_{0.9} \mathrm{Fe}_{2} \mathrm{O}_{4}$ nanocrystals were prepared by the simple coprecipitation route, then annealed at $900 \mathrm{C} / 4 \mathrm{~h}$ and precisely distinguished by XRD, FT-IR spectra, and HRTEM techniques. XRD inspection emphasized the egress of single-phase spinel configuration for these nanocrystals. Crystallite size $\mathrm{R}$ was $~ 36.265 \mathrm{~nm}$. FT-IR spectral plots emphasized the egress of the two essential spectral summits of Nano-spinels $v_{1}$ and $v_{2}$. Elicited parameters were dependent on $\mathrm{Ni}^{2+}, \mathrm{Co}^{2+}$, and $\mathrm{Fe}^{3+}$ cations in these Nano-spinels. HRTEM pics provided accumulations for nanoparticles, where average particle size value was $42.9 \mathrm{~nm}$ lightly rising than the crystallite size R. Photo-catalysis for $\mathbf{N i}_{0.1} \mathrm{Co}_{0.9} \mathrm{Fe}_{2} \mathrm{O}_{4}$ Nano-spinels was acquired through degradation of Crystal Violet $(\mathbf{C V})$ dye $\left(\mathbf{1} \times \mathbf{1 0}^{-5} \mathbf{M}\right)$ in aqueous soln under VL irradiation using 100 Watt Tungsten lamp fixed at $\sim 10 \mathrm{~cm}$ distance. Explicitly, utilization of $\mathbf{N i}_{0.1} \mathbf{C o}_{0.9} \mathbf{F e}_{2} \mathbf{O}_{4}$ nanocrystals confirmed obvious photo-degradation for $\mathbf{C V}$, with excellent efficiency, revealing marvellous strategy for advancement of cost-effective technics for waste $\mathrm{H} 2 \mathrm{O}$ recycling models, raising water quality and promoting efforts in treatment systems.

\section{References}

[1] S Bhukal, S Bansal, S Singhal, Magnetic Mn substituted cobalt zinc ferrite systems: Structural, electrical and magnetic properties and their role in photo-catalytic degradation of methyl orange azo dye, Physica B, 445 (2014) 48-55. http://dx.doi.org/10.1016/j.physb.2014.03.088

[2] T Li, Y Wang, Y He, J Cai, M Luo, L Zhao, Preparation and photocataytic property of $\mathrm{Sr}_{0.25} \mathrm{Bi}_{0.75} \mathrm{O}_{1.36}$ photocatalyst, Mater. Letters 74 (2012) 170 172. doi:10.1016/j.matlet.2012.01.078

[3] J Zeng, J Li, J Zhong, H Yang, Y Lu, G Wang, Improved Sun light photocatalytic activity of $\alpha-\mathrm{Fe}_{2} \mathrm{O}_{3}$ prepared with the assistance of CTAB, $\begin{array}{llll}\text { Materials } \quad \text { Letters, } & 160 & \text { (2015) }\end{array}$ http://dx.doi.org/10.1016/j.matlet.2015.08.037

[4] CP Yang, PA Smith, J Krupka, TW Button, The losses of microwave ferrites at communication frequencies, J. European Ceramic Society, 27 (2007) 2765-2770. doi:10.1016/j.jeurceramsoc.2006.11.004 
[5] E Casbeer, VK Sharma, X-Z Li, Synthesis and Photocatalytic Activity of Ferrites under Visible Light: A Review, Separation and Purification Technology, 87 (2012) 1-14. doi:10.1016/j.seppur.2011.11.034

[6] MA Amer, TM Meaz, SS Attalah, AI Ghoneim, Structural and magnetic characterization of the $\mathrm{Mg}_{0.2-x} \mathrm{Sr}_{x} \mathrm{Mn}_{0.8} \mathrm{Fe}_{2} \mathrm{O}_{4}$ nanoparticles, J. Magn. Magn. Mater., $363 \quad$ (2014) 60-65. http://dx.doi.org/10.1016/j.jmmm.2014.03.067

[7] SS Thakur, A Pathania, P Thakur, A Thakur, J-H Hsu, Improved structural, electrical and magnetic properties of $\mathrm{Mn}-\mathrm{Zn}-\mathrm{Cd}$ nanoferrites, Ceram. Intern., $\quad \underline{41} \quad$ (2015) 5072-5078. http://dx.doi.org/10.1016/j.ceramint.2014.12.077

[8] KK Bamzai, G Kour, B Kaur, M Arora, RP Pant, Infrared spectroscopic and electron paramagnetic resonance studies on Dy substituted magnesium ferrite, J. Magn. Magn. Mater., $345 \quad$ (2013) 255-260. http://dx.doi.org/10.1016/j.jmmm.2013.07.002

[9] KB Modi, SJ Shah, NB Pujara, TK Pathak, NH Vasoya, IG Jhala, Infrared spectral evolution, elastic, optical and thermodynamic properties study on mechanically milled $\mathrm{Ni}_{0.5} \mathrm{Zn}_{0.5} \mathrm{Fe}_{2} \mathrm{O}_{4}$ spinel ferrite, J. Mol. Str., 1049 (2013) 250-262. http://dx.doi.org/10.1016/j.molstruc.2013.06.051

[10] Q Wu, H Yang, $\mathrm{H}$ Zhu, Z Gao, Construction of $\mathrm{CNCs}^{-\mathrm{TiO}_{2}}$ heterojunctions with enhanced photocatalytic activity for crystal violet removal, Optik, 179 (2019) 195-206. https://doi.org/10.1016/j.ijleo.2018.10.153

[11] M Rahimi, M Eshraghi, P Kameli, Structural and magnetic characterizations of Cd substituted nickel ferrite nanoparticles, Ceram. Intern., 40 (2014) 15569-15575. http://dx.doi.org/10.1016/j.ceramint.2014.07.033

[12] G Dixit, JP Singh, RC Srivastava, HM Agrawal, Magnetic resonance study of $\mathrm{Ce}$ and $\mathrm{Gd}$ doped $\mathrm{NiFe}_{2} \mathrm{O}_{4}$ nanoparticles, J. Magn. Magn. Mater., 324 (2012) 479-483. doi:10.1016/j.jmmm.2011.08.027

[13] MA Amer, TM Meaz, SS Attalah, AI Ghoneim, Structural phase transition of as-synthesized $\mathrm{Sr}-\mathrm{Mn}$ nanoferrites by annealing temperature, J. Magn. Magn. Mater., $393 \quad$ (2015) 467-478. http://dx.doi.org/10.1016/j.jmmm.2015.06.013

[14] BD Cullity, (1978) Elements of X-ray diffraction, Second Edition, AddisonWesley Publishing Company, INC, United States of America, Congress catalog No 56-10137.

[15] MA Amer, TM Meaz, SS Attalah, AI Ghoneim, Structural phase transformation of as-prepared $\mathrm{Mg}-\mathrm{Mn}$ nanoferrites by annealing temperature, Mat. Char. 110 (2015) 197-207, http://dx.doi.org/10.1016/j.matchar.2015.10.032.

[16] V Kumar, Y Ali, RG Sonkawade, AS Dhaliwal, Effect of gamma irradiation on the properties of plastic bottle sheet, Nucl. Instrum. Methods Phys. \begin{tabular}{lllll}
\hline Res. Sec. $\quad$ B & $\underline{07}$ 10-14.
\end{tabular} http://dx.doi.org/10.1016/j.nimb.2012.07.007 
[17] N Lenin, RR Kanna, K Sakthipandi, AS Kumar, Structural, electrical and magnetic properties of $\mathrm{NiLa}_{\mathrm{x}} \mathrm{Fe}_{2-\mathrm{x}} \mathrm{O}_{4}$ Nanoferrites, Mater. Chem. and Phys. $212 \quad$ (2018) 385-393. 212:385-393. DOI: 10.1016/j.matchemphys.2018.03.062

[18] BD Cullity, (1972) Introduction to magnetic materials. Addison-Wesley Publishing, Inc., Boston.

[19] M Hashim, KS Alimuddin, SE Shirsath, RK Kotnala, H Chung, R Kumar, Structural properties and magnetic interactions in $\mathrm{Ni}_{0.5} \mathrm{Mg}_{0.5} \mathrm{Fe}_{2-\mathrm{x}} \mathrm{Cr}_{\mathrm{x}} \mathrm{O}_{4}$ $(0 \leq x \leq 1)$ ferrite nanoparticles, Powder Technology, 229 (2012) 37-44. doi:10.1016/j.powtec.2012.05.054

[20] SA Saafan, TM Meaz, EH El-Ghazzawy, MK El Nimr, MM Ayad, M Bakr, A.C. and D.C. conductivity of NiZn ferrite nanoparticles in wet and dry conditions. J. Magn. Magn. Mater., 322 (2010) 2369-2374. doi:10.1016/j.jmmm.2010.02.039

[21] SM Patange, SE Shirsath, KS Lohar, SG Algude, SR Kamble, N Kulkarni, DR Mane, KM Jadhav, Infrared spectral and elastic moduli study of $\mathrm{NiFe}_{2-\mathrm{x}} \mathrm{Cr}_{\mathrm{x}} \mathrm{O}_{4}$ nanocrystalline ferrites. J. Magn. Magn. Mater., 325 (2013) 107-111. http://dx.doi.org/10.1016/j.jmmm.2012.08.022

[22] SM Patange, SE Shirsath, SP Jadhav, VS Hogade, SR Kamble, KM Jadhav, Elastic properties of nanocrystalline aluminium substituted nickel ferrites prepared by co-precipitation method. J. Mol. Str., 1038 (2013) 40-44. http://dx.doi.org/10.1016/j.molstruc.2012.12.053

[23] I Sharifi, H Shokrollahi, Structural, Magnetic and Mössbauer evaluation of $\mathrm{Mn}$ substituted $\mathrm{Co}-\mathrm{Zn}$ ferrite nanoparticles synthesized by coprecipitation, J. Magn. Magn. Mater., 334 (2013) 36-40. http://dx.doi.org/10.1016/j.jmmm.2013.01.021

[24] K Shetty, SV Lokesh, D Rangappa, HP Nagaswarupa, H Nagabhushana, KS Anantharaju, SC Prashantha, YS Vidya, SC Sharma, Designing $\mathrm{MgFe}_{2} \mathrm{O}_{4}$ decorated on green mediated reduced graphene oxide sheets showing photocatalytic performance and luminescence property, Physica B, 507 (2017) 67-75. http://dx.doi.org/10.1016/j.physb.2016.11.021

[25] S Rajoriya, S Bargole, S George, VK Saharan, PR Gogate, AB Pandit, Synthesis and characterization of Samarium and Nitrogen doped $\mathrm{TiO}_{2}$ photocatalysts for photo-degradation of 4-Acetamidophenol in combination with hydrodynamic and acoustic cavitation, Sep. Pur. Tech., 209 (2019) 254-269. https://doi.org/10.1016/j.seppur.2018.07.036 